\title{
Conversations about Indigenous Peoples and Adjudication Interviews with G. Bennet, and S. Corry
}

\author{
Beatriz Barreiro Carril*
}

In the following interviews with some key actors of adjudication, B. Barreiro has been posing several key questions regarding the development of litigation on indigenous peoples' rights. Although there is still a long way ahead, national and international adjudication mechanisms are finding more sophisticated methods for the better protection of indigenous peoples' rights.

\section{Interview with Gordon Bennet}

Gordon Bennet is a barrister based in the UK who has worked extensively in support of indigenous peoples' rights for many decades. Most recently, Gordon has supported the legal argumentation in a complaint to the oversight mechanism of the Organisation for Economic Co-operation and Development (OECD) regarding the rights of the Dongria Kondh of India, and he was the main lawyer in support of the San in Botswana in a very significant case concerning their rights to land and natural resources after their eviction from their homeland in the Central Kalahari Game Reserve. ${ }^{1}$

B. Barreiro: How did you become interested in litigation for indigenous peoples' rights?

G. Bennet: I was a postgraduate student at Cambridge, in England, when it was suggested to me that research needed to be done on indigenous people's rights. At that time, which was late 1970 s early 1980 s, almost no work has been done on this issue, so I did some research and wrote a short monograph which was published by the Royal Anthropological Institute in England ${ }^{2}$ and it was really trough that work that I became interested in these issues, and I have remained in this issues for the last 20 or 30 years or more. I have to work both on indigenous rights and on commercial practice because I have a family to raise. Now I expend much more time on tribal rights that I once did, which is good.

Lecturer of International Law (Rey Juan Carlos University).

1. See 'Gordon Bennett: the go-to tribal rights guy', in The Lawyer, 31 October 2010, available at: <https://www.thelawyer.com/issues/1november-2010/gordon-bennett-the-go-to-tribal-rights-guy/>.

2. Bennett, Gordon, Aboriginal Rights in International Law, London: Royal Anthropological Institute in association with Survival International, 1978.
B. Barreiro: What is your general opinion of international legal norms concerning indigenous peoples, insofar as international law is made for and by the States?

G. Bennet: I think there are always limitations, it is better than it used to be, but it is still a very long way from perfect and I don't know whether it ever would be perfect. It is a long struggle and it must continue. I suppose one issue is that the major threat confronted by indigenous peoples these days tends to come not so much from governments but from multinational corporations because these are the people who want to exploit the land upon which indigenous communities depend. And the real problem obviously is that these multinational corporations are not subjects to International Law. There is now a claim movement to transfer the UN principles developed by John Ruggie ${ }^{3}$ into a binding treaty which will impose legally enforced obligations upon multinational enterprises, and that is a good thing, but it may take a very long time to go there, so in the meantime, I think, my generation of lawyers has to find other solutions, and this is usually about trying to trigger mechanisms inside the international financial institutions and in the UN and anywhere else.

You mentioned the OECD. ${ }^{4}$ That is one possible avenue, although that avenue has its problems because the OECDprocess is not compulsory, it may result in a decision but the decision is not binding upon the company. So, you have to depend upon the company's desire to protect its reputation for it to comply with the decision. And, of course a major problem is that there are companies which are most likely to trump upon tribal rights, they don't care, they do what they want and as long as they can keep their shares they are happy, they are prepared to accept that their reputation may suffer

3. Special Representative of the Secretary-General on the Issue of Human Rights and Transnational Corporations and Other Business Enterprises, Guiding Principles on Bussiness and Human Rights: Implementing the United Nations 'Protect, Respect and Remedy' Framework, Human Rights Council, princ., U.N. Doc. A/HRC/17/31 (Mar. 21, 2011) (by John Ruggie), available at <www.ohchr.org/documents/issues/ business/A.HRC.17.31.pdf>.

4. OECD States or States adhering to its "Guidelines for Multinational Enterprises Responsible Business" have the obligation of setting up National Contact Points (NCPs) for the mediation and conciliation in cases where non-observance of such guidelines may be at stake. See OECD 'OECD, Guidelines for Multinational Enterprises Responsible Business Conduct Matters', 2011. Available at <www.oecd.org/daf/inv/ mne/48004323.pdf>. 
because of the way they treat indigenous communities. So that is a problem. But I think this is getting better because companies do now care much more about their profile and their reputation and what they do. It is a long struggle that is better than it was and it will continue to get better, I think, as time goes on. But this is one reason why I have for the most part tried to focus on national legislation - national litigation -, because I think that in the short term that offers the best road to an effective remedy.

B. Barreiro: But the problem arrives when governments are not willing to apply courts' decisions. How do you see this?

G. Bennet: It depends which country you talk about and what kind of resolution you mean. In Botswana, which is the country with which I have most familiarity, I think that, generally speaking, the government would prefer to avoid bad court judgements. They do not want to be seen not complying with court judgements. They are very concerned about their reputation as democracy in which the rule of law prevails. They want to encourage foreign investors into the country and they are afraid that foreign investors will be discouraged if they see a government which fails to comply with court judgements. So that is one situation in which a court decision probably can be effective. But, of course there are many other countries in which that is less so, but still national judgements are so far the best route, I think, to force ruling in favour of tribal communities. It takes time but it is probably the best frame to do it.

B. Barreiro: Do you consider that national courts' decisions can have some preventive effects to protect future encroachments on indigenous peoples' rights?

G. Bennet: I think that it is very difficult to say but generally speaking I think that governments are much more aware now than they used to be about the risk of court actions. For example, again in Botswana when the Bushmen where evicted from the Central Kalahari, the government did not for a minute think that they would be sued, that they would be taken to the court. Now, I think, they are much more careful and much more hesitant about taking actions which might result in being taken to the court. I think that the same is true in other countries. In Kenya for example, there has been a number of court rulings against the government and although unfortunately these rulings have been proved difficult, governments would prefer to avoid things of that kind because of the impact this may have in the government's reputation abroad and on the ability to attract foreign investment.

B. Barreiro: The issue of conservation versus indigenous peoples' rights is very present in your career. The case against World Wildlife Fund (WWF) before the OECD ${ }^{5}$ is paradigmatic of how

5. See National Contact Point of Switzerland, 'Final Statement Specific Instance regarding the World Wide Fund for Nature International (WWF) submitted by the Survival International Charitable Trust Berne', 21 November 2017, available at National Contact Point of Switzerland Final Statement Specific Instance regarding the World Wide Fund for wrong understandings of the needs for protecting nature can negatively impact on indigenous peoples' rights.

G. Bennet: I think that conservationists mostly consider themselves to be just conservationists. They think that they are responsible for conserving natural flora and fauna, they do not see that there is responsibility to protect the people who are affected by their projects, and it has taken them a long time to understand that you cannot separate the two. But if you have a project in a remote and isolated place in which there are local indigenous populations, any attempt to create a protected area in their land will have enormous repercussions for them, and I think that the broad response has been to say "well, that is matter of the government, and not for us" and it has taken them a lot of time to realize that just is not the case. If you look again into the Ruggie principles they demonstrate that companies have a responsibility to respect human rights and they can only do that if they firstly consider the likely impact of a project upon those rights and if then they take active steps to avoid or mitigate that impact. For the most part they have singly failed to do that until now. They will have to learn that they need to do this in their own interest as much as in the interest of local communities.

I think that WWF is probably one example of this. When they went into Cameroon they simply did not consider the position of the Baka. They thought that the Baka could take care of themselves or that the government would take care of them, and it was not part of their responsibility to consider how the effects of the protected area they wished to create, might affect the livelihoods of the Baka. But that is a major mistake. The Baka have paid the price. Something has to be done to change that and I suspect that the answer must lie within the conservation movement itself. In the end, the people who support the conservation movements, the individual subscribers who support WWF have to come together and insist that their organization conduct its affairs in a way that properly respects indigenous communities. And that would very often mean some form of co-management or co-partnership. But the trouble of all this, of course is that it is slow, it takes time, it costs money, and organisations like WWF think that they don't have time. Everything is urgent, everything has to be done the day before yesterday, otherwise the elephants, the ostriches, all will be dead. That is their approach, but unfortunately that does not work. If they do not have local people on their side the project will fail. And I think that many conservationists don't accept that. So, there has to be some mutual understanding, some mutual discussions about how we resolve these problems. It will not happen overnight. But it should happen and I hope that in the next ten or fifteen years we should see if we will progress.

B. Barreiro: In fact the consultation processes with indigenous communities need time, because

Nature International (WWF) submitted by the Survival International Charitable Trust Berne, 21 November 2017. 
of the differences concerning languages, traditions, particular legal systems, etc. And I imagine - going back to your role as a lawyer - that it would be difficult to do this translation between different cultural and legal languages, right?

G. Bennet: That is a possible problem but I do not think that this is the main problem. There are some quite complicated legal provisions in Cameroon, Botswana and elsewhere, but for the most part the law can be expressed in fairly simple language. Lawyers have a total habit of complicating things, of using fancy words where simple words would do. And we need to rid ourselves of that habit. So I do not think that the ability to express a legal situation is a real problem. I suspect the real problem is that indigenous communities have been asked to say yes or no to a project which may continue for twenty or thirty years. And what is very difficult for them indeed is to know what the consequences of that project will be and what the consequences for them will be if they say no to the project. So you have to decide, I suppose, what kind of information they need to make a proper decision and then to provide them the information in a clear and accessible way. My experience is that of course tribal peoples are like everybody else: some are stupid, some are sensible, some are intelligent, and they are just as able as anybody else to understand what they have been told, provided they are told it in a proper way and that they are given time to consider it and discuss it amongst themselves. And it may take quite a lot of time, especially in small societies in which there is no tradition of leaders making decisions on behalf of the group as a whole. Everybody has to be involved, and that requires a lot of work, and there can be problems too with some societies - although not as many as we would have believed - in which women are not given a proper say in the decisions that affect them. And again, it might be extensive to Bushmen societies, where women are very well able to understand what is going on, and quite often better able than a man to make decisions about it. And they need to be told, time and time again, that they will not be punished if they make the 'wrong' choice, that is to say, if they make the decision that is not the decision the government wants of them. If people are afraid of governments, if they are afraid of officials, if they are afraid of large companies, there is a strong temptation to reach a decision which they do not want, in order to keep out of the problem. And that is something you have to go against all the time.

B. Barreiro: So, somehow, there is a need to act with precaution, in the way environmental law has suggested to do through the creation of 'precautionary principle': if after an impact study there are risks to the environment, there will be no action. So, there is the need to establish a really binding principle like that for indigenous peoples as well as to make clear the difference between consultation and consent, this last one being the requirement which needs to count.

G. Bennet: Yes, exactly. In fact environmentalism has a very important principle called the precautionary prin- ciple, that is to say, if you are not sure of the consequences of a particular course of action, do not do it. Be cautious; only take steps when you are confident. But indigenous peoples should be warned of the risks and they should be told about the benefits.

B. Barreiro: Thank you very much, Gordon, what would be your final statement for closing this interview?

G. Bennet: I would say that this is an area in which of course lawyers are required the same as conservationists and other experts. But it would be far better if lawyers and conservationists come from among indigenous peoples themselves. They will do it. And we need to do all that we can to encourage that and to persuade indigenous peoples that they can do this, that they should do this and that the governments must make facilities available to make it possible for them to do it.

\section{Interview with Stephen Corry}

Anthropologist Stephen Corry directs Survival International, a key non-governmental organization in the defence of indigenous peoples' rights. Survival focus its work on raising awareness of violations of indigenous rights all over the world but it funds also judicial claims in defence of such rights. Survival International has supported several cases of adjudication for the protection of indigenous peoples across the globe.

B. Barreiro: How did you start working for the defence of indigenous peoples' rights? How was Survival [International] created?

S. Corry: Survival calls itself the global movement for tribal peoples' rights. It perceives itself as working on several overarching campaigns about specific issues such as uncontacted tribes or the relationship between conservation and tribal peoples. As well as this, it sees itself as trying to create a groundswell of public opinion in favour of tribal peoples. We now have supporters in about a hundred countries. What makes Survival different from almost all other organizations in this field is that it is largely funded by individual supporters, not particularly rich people necessarily but a lot of people giving a little amount of money. That feeds into our objective to make the world a better place for tribal peoples because we think this is not going to happen unless there is public opinion in favour of tribal peoples. So, the long-term focus is public opinion. I myself became involved in it because I encountered tribal peoples for the first time when I was doing something else, which was travelling in Nepal, and I was very surprised at that time - this was 1970 - because I had always assumed before, that everybody wanted the kind of development which the West then (and now, more than in 1970) was - and is - trying to present as the inevitable way in which all peoples want to live, and I realized that this simply was not true, that there were plenty of peoples in the world who did not want to live according to those norms. So in that sense I became aware of the fact that 
the history of western, whatever you call it: society, development, is a lie, and tribal peoples kind of epitomize how this lie works in practice. Because the usual accepted narrative was that they have always wanted to catch up with us, that they wanted all the things that we knew as central to modern life and this is simply not true. The term 'Paraguay's reductions' is very accurate: It is an attempt to reduce them to - at best - servant workers. And actually in the process of this a lot of them, of course, are in one way or another killed as individuals or as peoples.

So, Survival first started in 1969 . When I came across it in 1972 I became a volunteer for it. Survival identified the problem in exactly the same way as it does today the problem is the lack of respect for lands rights - but it had not really got any particular formula of what to do about this. The focus on campaigning - and I was mounting a popular public campaign on this specific issue - started at the end of the seventies with a campaign in Brazil which was vigorously pushed by a little NGO consisting really of one or two people. So we magnified that campaign up to the international level, working in different languages, working in different countries and basically pushing it to the press and to the media. And that is still a very large part of what Survival does.

B. Barreiro: So, I see that the focus is put in international public opinion. This way of taking advantage of globalization which has also negative consequences for indigenous peoples' rights is interesting. Concerning the issue of International Law - where there are new developments concerning indigenous peoples' rights - do you think that they are enough?

S. Corry: No, they can never be enough. There are many countries that don't apply the 10 year-old UN Declaration. There is no country in which tribal peoples, where they are minority, have their rights properly respected and this obviously can go very deep. And the kind of approaches taken in countries like Australia or Canada have to cope with the fact that there is a generation of violent dispossession which took place and which is being maintained through education systems, approaches to development and approaches to the kind of problems which these peoples are facing today: addictions, suicide, imprisonment, domestic violence. So, in areas where the violence which has been perpetrated to these peoples has been internalized, as in countries like Australia and Canada or the United States, then obviously the question of simple respect for land rights is no longer enough. There is a hundred and fifty years old oppression which needs to be addressed and which is not addressed at the moment. So the legal situation, or what the law says in a country which has (on paper) relatively good laws, is not the main question, the main question is how these laws are actually applied. So if the law says you cannot do development projects on tribal or indigenous peoples lands without their proper consent, which is broadly the principle behind the UN Declaration and behind the early ILO Convention, if you take this as the starting point, that in itself is complicated, obviously, because it raises questions such as how do you secure that consent, what exactly does this mean: who has to consent? In a society where there is a lack of a pyramidal political structure, that presents, obviously, a problem. If a mining company wants to mine on indigenous peoples' lands, how do they obtain consent? Whose consent? How do they go about that process? So, the law can appear to be OK, but in real life of course it is the question of how it is put into practice. The nation state system and its legal system still cannot properly cope with the fact that there are indigenous peoples who exists outside those systems, and of course there are still many who have never heard of the country they are supposed to live in, leave alone form part of any integrated part of that country. There are many uncontacted tribal peoples.

So, all those questions are an issue, and International Law is moving in the right direction globally but extremely slowly, actually. I mean, the first ILO Convention was in 1953, that is two generations ago and the UN Declaration took 20 years to actually be formulated and there are still problems with that, obviously. So International Law is moving very slowly apparently in the right direction. Some countries are becoming progressively more aware of these issues and other countries are just going backwards: Brazil is an attempt to move things back thirty or forty years because political movements are coming and going, being more progressive or less progressive and obviously these issues are just as important as any legal instrument, and that is actually why a big part of Survival's work is to try to shape public opinion. And the judiciary is as susceptible to public opinion as any other sector of the population, obviously.

B. Barreiro: Regarding the issue of education systems you were referring to, the decision of the Truth and Reconciliation Commission of Canada stating that the education system for indigenous children constituted a cultural genocide is a good step, right?

S. Corry: Yes, but I think that there is a bit danger if we talk too much about culture because the result of the education system not only in Canada but very much in Australia and in US certainly set out to destroy peoples' culture, but it also destroyed individuals: a lot of individuals did not survive the school system. The damage is not only cultural, it's physical: addictions, suicide, domestic violence, these kinds of issues.

B. Barreiro: What are the criteria according to which Survival decides to support a case for bringing it before court?

S. Corry: Actually defining the criteria is very difficult. In the Botswana case we needed to be convinced firstly that the Bushmen themselves were entirely supportive of the idea that their homeland was within the Central Kalahari Game Reserve, and that they did not want to be moved from it on a very deep level. If there'd been a casual “well, we don't really want to be moved but if you give us enough compensation then $\mathrm{OK}$," then we 
would not have supported the court case. So, we spent a lot of time, many years, establishing what these people wanted. This meant going to the communities, talking to people, not just relying on the nearest thing to political leaders (some were emerging) but it meant talking to people at the community level including women and old and young people. That is, people who are not usually so vociferous in any emerging political movement. So that is actually key.

We then had to decide, what are the chances of a fair hearing? In many countries courts are not the places where you go to receive a fair hearing! They are places where the controlling elites use the law to support what they want. So, we have to be reasonably confident that we could at least have a chance of securing a fair hearing. In the Botswana system at that time we knew that the appeal court was still composed of several judges from outside of the country, who were unlikely to be influenced by the dominate elite within Botswana. So, we were hopeful that even if the case was lost, the appeal court might give it a chance. We also had no idea how long a case might last, and therefor how many resources would be needed to be put into this. That's a feature of this kind of work. We took a gamble that our supporters would support financially the costs involved with helping the Bushmen to bring this case. We had to know that the Bushmen were not only adamant about their own resistance to be evicted but that they were actually willing to go through the court system to fight this, rather than fighting in other ways. There is of course a risk involved in this, because, had they lost this case it would have presented a precedent on the other side. So we can look at it now, having won the case. If they had lost the case we would be looking at it in a very different way. It's always a risk.

Survival has supported lots of local court actions in other countries, places like Brazil for instance, where indigenous people are going to court to try to get their land back and some of these are successful and some of them are not. Some of them we do not publicize very widely, or even at all. Sometimes we do not talk about how we are helping these peoples taking their issues to courts. So, the real criteria are that the peoples themselves have to be strongly behind it with determination and we have to have some sense that there is at least a chance of winning it. There are other secondary advantages. The Botswana case is a good example because we did not expect this campaign, this court case to really influence public opinion in Botswana. We were told at the beginning of our campaign that we had no chance of influencing public opinion in Botswana. There is very little orthodox media. There is a weekly and a Sunday independent newspaper and there is a daily government controlled newspaper. The government controls the television. When we started, there was no Botswana television. To our surprise, over the years we found that the Botswana media did actually move quite a long way to be on the Bushmen's side. So, the initial assumption (that the Bushmen did not know what was good for them and that the best thing for them would be to leave their lands and start living outside like other peoples from Botswana) changed over the years to the point where there was a recognition of the part of the media and then of the population that if the Bushmen didn't want to do that, they had the right not to. So the whole system has to go hand in hand with a shift in public opinion. A very good example is slavery abolition where public opinion had to be shifted from being in favour of slavery. Slavery at the time was viewed to be not only beneficial for the British Empire but also to the slaves, since it was considered to take them out of their 'pagan', 'savage' existence and give them the benefits of English 'civilization'. So, in a similar way, in Botswana in 2002, when evictions happened, the general perception of the public was that this was good for the Bushmen. So that had to be shifted in the same way as the court had to look at these things and try to arrive at a position that was fair to Bushmen.

B. Barreiro: What about the difference of bringing a case into the national and international level, for instance, through the quasi-judicial system of some organs of United Nations, or before regional international human rights courts?

S. Corry: Again it depends on the case. Survival as a movement and as an organization knows that in cases where there is no respect for rule of law or in cases of warfare - whether it is declared or not - there is very little point in trying to do anything within the judicial system and there might be very little point in trying to move national public opinion. There was no point during the Guatemalan Civil War to try to influence the Guatemalan media, for example. One could try to influence the international media. No country exists in isolation. Countries have allies and it's possible to think strategically about how to put pressure on a country through the public opinion of its allies, or its neighbours. But there is probably a feature of this work which is quite common which is that national views often don't tend to see the relevance of international work. This applies to national actors like national NGO's, sometimes the national press. Actually it is quite interesting that the indigenous peoples themselves - at least some individuals - if you show them how the international system works (both in terms of media and in terms of notions of human rights), they can have a much more sophisticated approach to the international work than some of the local NGO's.

If people have been oppressed for five hundred years in a given country they can begin to think that the entire country is against them. Obviously, it isn't: there are always people everywhere that are supportive of international rights, but sometimes within the international context (because progressive values are generally accepted internationally, at least until recently), there is a general perception that progressive values are increasing and gaining more traction as the decades pass. And this is how the international context can be applied to the national context. But it depends very much on the country. Regarding our work in Cameroon, trying to stop the violation of the rights of the Baka by eco-guards and 
people supported by the conservation movement, there is little active media interest in this in Cameroon itself. It's therefore a very different situation than that of Botswana and it's almost certain that international work is going to have more impact than simply trying to work locally.

B. Barreiro: Survival works in the whole world. What are the differences you have experienced regarding the different areas?

S. Corry: A very important difference is the strength of the indigenous peoples themselves. In areas where there are relatively strong it is a very different situation. In a country like Botswana for instance, firstly the elite claims there's no such thing as indigenous peoples: they do not exit. They say all Botswana citizens are indigenous. The Bushmen are numerically quite small with only a few tens of thousands still holding very strongly to Bushman identity and there are no other indigenous peoples in the country. So, they are very much in a politically weak position. That is very different to the Amazon countries where there is a quite strong indigenous movement. In these cases there is a strong and quite politicized movement which started in some places in the $1960 \mathrm{~s}$, and later in other places.

There is a paradoxical situation in which nowadays, if you look at the Amazonia, broadly speaking, until recently the indigenous movement did not need much outside support. They are quite capable of supporting their owns rights even if there are particular issues, such as uncontacted peoples that are not represented by any organization. And there are issues now, particularly in Brazil, of a row-back, a return to oppression and the denial of indigenous rights, following several decades in which broadly (with setbacks, of course) indigenous rights were going upwards. So, it depends very much on the country and in continents like Africa or Asia there is this additional issue of who is indigenous. What makes them indigenous? What gives them rights to land? That brings us into other questions such as what is ethnicity, what is identity, what is an indigenous people, how do you define it, how do you self-define? These issues were deliberately avoided in the UN Declaration. There is no attempt to define who are an indigenous people. Whether that is a good idea I do not know. I think that the ILO Convention has definitions that are not that bad and that are broadly workable. And in real life of course people have multiple identities and that applies to many indigenous peoples as well.

Some countries like Brazil, as mentioned before are moving backwards in terms of indigenous peoples' rights, whereas in others, like Botswana in the last 15 or 20 years, there are some steps forward, at least in terms of visibility.

B. Barreiro: Thank you very much, Stephen. Would you like to add something more in to close this interview?

S. Corry: From my perspective, the most important thing is to realize that these issues are not actually remote or exotic; they are about racism, about nationalism, about control of people, about dominant elites.
They are about progressive values or the reverse. It is important to understand that there are peoples in the world who do not want to live in the dominant way. Although indigenous peoples do not threaten any nation state politically, their ideology is actually very threatening because they are a living example of how human beings have found thousands of different ways to live. They are all very different. Many of them are very successful. In fact if you look at the different ways to live, in that sense indigenous peoples constitute a majority. They represent far more variety than anybody else. What they represent could not be more important about our decisions, about what our grand-children and their grand-children are going to think, about how they are going to behave. 